\title{
DETECTION OF SOLAR NEUTRINOS
}

R. M. Brugger

\section{Aerojet nuclear Company}

NATIONAL REACTOR TESTING STATION Idaho Falls, Idaho - 8340 I

\section{MASTER}

DISTRIBUTION OF. THIS DOCUMENT IS UNLIMITED

DATE PUBLISHED-AUGUST 1974

PREPARED FOR THE

\section{U. S. ATOMIC ENERGY COMMISSION}

IDAHO OPERATIONS OFFICE UNDER CONTRACT AT(10-1)-1375 


\section{DISCLAIMER}

This report was prepared as an account of work sponsored by an agency of the United States Government. Neither the United States Government nor any agency Thereof, nor any of their employees, makes any warranty, express or implied, or assumes any legal liability or responsibility for the accuracy, completeness, or usefulness of any information, apparatus, product, or process disclosed, or represents that its use would not infringe privately owned rights. Reference herein to any specific commercial product, process, or service by trade name, trademark, manufacturer, or otherwise does not necessarily constitute or imply its endorsement, recommendation, or favoring by the United States Government or any agency thereof. The views and opinions of authors expressed herein do not necessarily state or reflect those of the United States Government or any agency thereof. 


\section{DISCLAIMER}

Portions of this document may be illegible in electronic image products. Images are produced from the best available original document. 


\section{Printed In the United States of America Avallable from}

Natlonal Technical Information Servica

U. S. Department of Commerce

5285 Port Royal Road

Springfield, Virginia 22151

Price: Printed Copy $\$ 4.00 ;$ Microfiche $\$ 1.45$

\section{LEGAL NOTICE}

This report was prepared as an account of work sponsored by the United States Government. Neither the United States nor the United States Atomic Energy Commission, nor any of their employees, nor any of their contractors. subeontracters, or their employees, makes any warranty, express or implied, or assumes any legal liability or responsibility for the accuracy, completeness or usefulness of any information, apparatus, product or process disclosed, or represents that its use would not infringe privately owned rights. 
Commision,

Commission, nor any of their employees, nor any of

their contractors, subcontractors, or their employees

makes any warranty, express or implied or assumes any

legal liability or responsibility for the accuracy any

pleteness or usefulness of any information app, com-

product or process disclosed, or represents, apparatus,

would not infringe privately owned reprents that its use

4

AEROJET NUCLEAR COMPANY

Date Published -- August 1974

PREPARED FOR THE U. S. ATOMIC ENERGY COMMISSION IDAHO OPERATIONS OFFICE

UNDER CONTRACT NO. AT(10-1)-1375 


\section{AESTRACT}

An experiment is suggested by which the gentle interaction of neutrinos with nuclei might be detected. The experiment is to recora the temperature of selected volumes of the earth or the moon to observe changes as a function of the solar year in the heat generation rate caused by the oscillating neutrino flux from the sun striking the earth and moon. 


\section{DETECTION OF SOLAR NEUTRINOS}

\section{R. M. Brugger}

Lubkin $^{(1)}$ suggests that neutrinos may interact with matter through gentle interactions with nuclei. He predicts an energy loss of $\sim 5 \times 10^{-7}$ $\mathrm{eV}\left(\frac{\mathrm{cm}^{2}}{\text { gli }}\right)$ per neutrino (or $\sim 8 \times 10^{-19}$ ergs $\left(\frac{\mathrm{cm}^{2}}{\mathrm{gm}}\right)$ per neutrino). Assuming that the average density of the earth is $D=5 \mathrm{gm} / \mathrm{cc}$, this energy transfer would produce about $\Delta E_{n}=4 \times 10^{-18} \frac{\text { ergs }}{\mathrm{cc}}$ per neutrino in the earth.

Trimble and Reines (2), reviewing the "Solar Neutrino Problem", list the sources of solar neutrino flux and the expected flux at the earth. The principal source is the $H+H \rightarrow D+e^{+}+v(0-0.402 \mathrm{MeV})$ with a projected flux on earth of $6.0 \times 10^{10}$ neutrinos $/ \mathrm{cm}^{2} \mathrm{sec}$. The next most intense source, $B e+e^{-} \rightarrow{ }^{7} L i+v(0.86 \mathrm{MeV})$, is projected to produce a flux of $4.5 \times 10^{9}$ neutrinos $/ \mathrm{cm}^{2} \mathrm{sec}$ or a factor of 10 less. Assuming the flux of neutrinos at the earth is $6 \times 10^{10}$ neutrinos $/ \mathrm{cm}^{2} \mathrm{sec}$, then the energy transferred by Lubkin's gentle interaction to $1 \mathrm{cc}$ of earth material is:

$\Delta E_{e} \cong 4 \times 10^{-18} \times 6 \times 10^{10} \cong 2.4 \times 10^{-15} \frac{\text { watts }}{c c} \cong 5.5 \times 10^{-16} \frac{\mathrm{cal}}{\mathrm{cc} \mathrm{sec}}$

Blackwe11 (3) discusses heat sources in the earth and describes two models. One model has all the heat generated in the crust to depth $b$ with a small (maybe zero) uniform source below. A second model has a distribution:

$$
A(x)=A_{0} \exp \left(\frac{-x}{b}\right)
$$

where $A_{0}$ is the measured surface heat generation, $A$ is the heat generation at depth $x$ and the constant $b$ ranges from 7.5 to $10 \mathrm{~km}$. Blackwell 
quotes heat generation in units of $10^{-13} \mathrm{cal} / \mathrm{cc}-\mathrm{sec}$, which equals one heat generation unit, hgu. The average heat generation rate in the crust of the earth is about 5 hgu. Thus the heat generated in the earth by neutrinos might represent about $0.1 \%$ of the average heat generated in the crust of the earth by uranium and thorium decay but may represent a larger percent of the heat generation rate deeper in the earth, say at $10 \mathrm{~km}$, or at specific locations in the earth where the heat generation rates are lower than normal, say the Sierra Nevada range. The deepest wells drilled to date are about $7.6 \mathrm{~km}$ or near the limit where the heat generation from neutrinos might be measurable compared to other sources.

A possible experiment to detect neutrinos would be to place thermometers deep in a dry well at a place where the earth's heat generation sources are small and constant. Then one would search for a temperature change related to some change in the neutrino flux, say the earth's rotation about its axis or the earth's rotation about the sun.

First, consider detecting the absorption of neutrinos as the earth rotates about its axis. The earth is about 4,000 miles in radius or $5.3 \times 10^{8} \mathrm{~cm}$. Again using $D=5 \mathrm{gm} / \mathrm{cc}$ the total energy 1ost by Lubkin's interaction as a neutrino traverses the earth would be:

$$
E_{\text {total loss }}=5.3 \times 10^{8} \times 5 \times 10^{-7} \mathrm{eV} \times 5=1.3 \mathrm{KeV} .
$$

This loss appears small compared to the total energy of most neutrinos so that it would be difficult to do an experiment in which a search is made for a response of the thermometer with the earth rotating between the sun and the thermometer, that is from day to night. 
ivext, consider the possibility of detecting the oscillation of the flux of neutrinos as the earth rotates about the sun. The earth as it circumscribes the sun, has an eccentricity of 0.02 , thus the apogee to perigee ratio is 1.04 . Since the flux of neutrinos from the sun hitting the earth will vary as the distance squared, the expected fluctuation in the heat generation rate of neutrinos from apogee to perigee should be $2-1.04^{2}$ or about $8 \%$ with a period of 365 days. If a location within the earth with a low and constant heat source could be used, this $8 \%$ fluctuation on a 365-day time span might be observed.

The effect of heating by neutrinos might be enhanced if a volume were located that had a higher than average density and/or a lower than average heat generation rate. Also the temperature vs. time records should be frequency analyzed to extract the 365-day response from the "noise" of other heat sources. It is estimated that the $5.5 \times 10^{-16}$ cal/cc-sec might produce temperature fluctuations of $1 / 1000^{\circ} \mathrm{C}$. Present precision in measuring the temperature in the earth is $\sim 1 / 100^{\circ} \mathrm{C}$ over shorter periods of time than would be required for this determination. McLean ${ }^{(4)}$ has measured the atmospheric conditions in Carlsbad Caverns. At the upper levels the climate is effected by air circulation but at the deepest levels the air is measured to be $26.1^{\circ} \mathrm{C}$ unchanging within the $0.1^{\circ}$ accuracy of the thermometer. These measurements suggest that a location can be found that would reflect only the geothermal heat source. Improved temperature measurement techniques by 1 to 2 orders of magnitude might snow the neutrino effect.

Another possible measurement location might be on the moon. There the heat source is estimated to $5 \mathrm{se}$ about $1 \mathrm{hgu}$ and there is some uncertainty as to the source of this heat. (5) For a period of 14 earth 
days long, the thermometer would be on the dark side of the moon which should provide a low and constant heat sirik. Thus measurements of the temperature in which one wishes to observe changes due to a change in the heat source from neutrinos would be accentuated by this low and constant sink. The 365-earth-day period would have to be extracted from the 28-earth-day period caused by the moon's rotation.

One discrepancy in the above estimates is that both Lubkin's maximum energy 1oss/neutrino was used and the maximum expected flux at the earth was assumed. Since Lubkin estililated the former to explain the supposed reduced flux measured by Davis, these are mutually exclusive; an intermediate value for both might be more realistic.

The author has not been able to identify any wells that have been rionitored for temperature over a long period of time which might show the heating effect of neutrinos suggested by Lubkin's interactions. The order of magnitude refinement in sensitivity suggested needed for the experiments seems feasible and much easier to attain than the 8 and 5 orciers of magnitude factor. of infeasibility suggested by Lubkin for observing neutrinos from LAMPF or from a reactor. 
The author acknowledges with thanks helpful discussions with J. F. Kunze and R. L. Heath, Aerojet Nuclear Company, C. R. Nichols, Boise State University; Charles Mankin, Leonard Observatory, University of Oklahoma; David Blackwell, Southern Methodist University; Marcus Langseth, Lamont-Doherty Geological Observatory; John Sass, USGS; Fred Dix; American Association of Petroleum Geologists; John McLean, USGS, Frederick Reines, University of California; and R. S. Shankland and L. L. Foldy, Case Western Reserve University. 


\section{REFERENCES}

1. E. Lubkin, Phys. Lett., 46A, Ho. 7, 431-432 (February 11, 1974).

2. V. Trimble and R. Reines, Rev. of Mod. Phys., 45, No. 1, 1-5, (January 1973).

3. D. D. Blackwe11, The Thermal Structure of the Continental Crust, Geophysical Monograph Series, Vol. 44, 169-184. See also G. Schubert and 0. L. Anderson, Physics Today, (March 1974), p. 28.

4. J. McLean, private communication of information in Micro Climate in Carlsbad Caverns, USGS Open File Report (May 1971).

5. NASA-SP-289, Chapter 11, and NASA-SP-330, Chapter 9. See a7so D. L. Anderson, Physics Today, (March 1974), p." 44. 